\title{
12. Seminarium Open Access w Bibliotece Uniwersytetu Łódzkiego 26-29 października 2021 r.
}

Międzynarodowy Tydzień Otwartej Nauki to święto wszystkich tych, którym bliskie są idee powszechnego i równego dostępu do nauki: publikacji, danych badawczych i zasobów edukacyjnych. W 2021 roku XII Open Access Week (25-31 października) na całym świecie obchodzono pod hasłem: „It Matters How We Open Knowledge: Building Structural Equity" - wyjątkowo silnie akcentującym potrzebę budowania równości od podstaw, przy tym równości niezależnej od płci, pochodzenia czy miejsca zamieszkania osób chcących uczestniczyć w procesie edukacji lub korzystających z osiągnięć badań naukowych.

Biblioteka Uniwersytetu Łódzkiego od dwunastu lat aktywnie włącza się w działalność na rzecz promocji otwartego dostępu do nauki, organizując seminaria Open Access Week, każdorazowo obejmowane Patronatem Honorowym Rektora Uniwersytetu Łódzkiego. W tej edycji, dwunastej, do patronów wydarzenia dołączyły „Zagadnienia Rodzajów Literackich" - czasopismo wydawane w diamentowym modelu otwartości, które nie pobiera od autorów ani czytelników opłat za publikację i dostęp do wersji online publikowanych tekstów. „Zagadnienia Rodzajów Literackich” dołączyły do wieloletniego patrona wydarzenia, jakim jest Koalicja Otwartej Edukacji — organizacja działająca na rzecz popularyzacji dobrych praktyk i wiedzy dotyczącej tworzenia i upowszechniania otwartych zasobów edukacyjnych, naukowych i zasobów kultury.

Obchody XII Tygodnia Otwartej Nauki w Bibliotece UŁ w tym roku miały formę bezpłatnych warsztatów online adresowanych do badaczy i dydaktyków z Uniwersytetu Łódzkiego - pracowników, doktorantów oraz studentów. Pierwsze ze szkoleń, prowadzone przez 
Magdalenę Szuflitę-Żurawską z Politechniki Gdańskiej, dotyczyło coraz bardziej wymagającego naszej uwagi tematu danych badawczych. Zwiększanie świadomości naukowców w kwestii otwierania danych badawczych, a nie tylko publikacji ich wyników, okazuje się niezwykle ważne w świecie, gdzie — jak pokazała pandemia COVID-19 - natychmiastowy powszechny dostęp do danych może przynosić wymierne rezultaty, w tym ratować ludzkie życie. Prowadząca pokazała pracownikom naukowym i doktorantom UŁ, jak zarządzać danymi badawczymi w trakcie trwania projektu naukowego, a także jak poprawnie przygotować Plan Zarządzania Danymi, czyli dokument wymagany coraz częściej m.in. przez fundatorów badań. Opowiedziała również o możliwościach deponowania danych w przeznaczonych do tego repozytoriach.

Drugie spotkanie poświęcone było publikowaniu w modelu otwartym w ramach umów podpisanych m.in. przez Uniwersytet Łódzki z największymi wydawcami czasopism naukowych. Zaproszony w roli eksperta Grzegorz Grochowski reprezentujący zespół Wirtualnej Biblioteki Nauki Interdyscyplinarnego Centrum Modelowania Matematycznego i Komputerowego Uniwersytetu Warszawskiego przedstawił założenia programów publikowania otwartego i zapoznał uczestników szkolenia z możliwościami, jakie programy te otwierają przed naukowcem. Publikowanie wyników badań w wysoko punktowanych zagranicznych czasopismach naukowych to temat, który od lat porusza środowisko naukowe, przede wszystkim ze względu na opłaty APC (ang. Article Processing Charge) — niekiedy sięgające kilku tysięcy dolarów czy euro. Umowy krajowe i konsorcyjne zawierane przez polskie uczelnie z wydawcami, takimi jak Elsevier czy Springer, stanowią w tej chwili filar finansowego wsparcia naukowców w procesie publikowania ich prac w formacie open access. Programy publikowania otwartego Wirtualnej Biblioteki Nauki cieszą się więc niesłabnącym zainteresowaniem ze strony instytucji naukowych i samych badaczy. Nieznane są jednak losy projektu w 2022 roku - Ministerstwo Edukacji i Nauki nie podjęło jeszcze decyzji w sprawie jego dofinansowania.

Podczas trzecich warsztatów Aleksandra Czetwertyńska z Centrum Cyfrowego przeprowadziła dydaktyków i studentów przez proces tworzenia i udostępniania otwartych zasobów edukacyjnych. Okazuje się, że zagadnienia z zakresu prawa autorskiego dla nauczycieli i licencje Creative Commons wciąż wymagają utrwalania w świadomości uczestników procesu kształcenia. Prowadząca zapoznała grupę z możliwościami tworzenia własnych otwartych zasobów na podstawie tych już istniejących, a także pokazała bezpłatne narzędzia online, za pomocą których treści można projektować, łączyć i modyfikować.

Ostatnie szkolenie w ramach Seminarium dotyczyło narzędzi wspierających badacza w czasie jego pracy naukowej. Dwoje reprezentantów Elseviera - Paulina Milewska i Bartłomiej Więckowski - przedstawiło pracownikom i doktorantom z Uniwersytetu Łódzkiego możliwości, jakie dają: ogromna baza abstraktów i cytowań Scopus, kolekcja prac naukowych i czasopism ScienceDirect oraz platforma analityczna SciVal. Narzędzia te służą zarówno bibliotekom naukowym do sporządzania analiz bibliometrycznych, jak i mogą się okazać użyteczne w codziennej pracy naukowej, m.in. w gromadzeniu bibliografii, identyfikacji naukowca, analizie cytowań, wyborze czasopisma do publikacji, śledzeniu nowości z danej dyscypliny czy tematyki. Prowadzący pokazali szereg funkcjonalności ułatwiających zarządzanie informacją w czasie prowadzenia badań naukowych.

12. Seminarium Open Access stało się okazją do dyskusji na temat dostępności zasobów nauki i realnych możliwości, jakie ośrodki naukowe dają swoim pracownikom i studentom, 
by mogli oni aktywnie działać na rzecz rozwoju Otwartej Nauki i dzielić się własną pracą z całym światem. Zgodnie z ideą otwartości prezentacje nadesłane po spotkaniach przez prowadzących zostały zamieszczone w Repozytorium Uniwersytetu Łódzkiego ${ }^{1}$ na otwartej licencji - by mogły służyć każdemu. W warsztatach organizowanych przez Oddział Informacji Naukowej i Analiz Bibliometrycznych Biblioteki UŁ wzięło udział blisko stu zainteresowanych badaczy i dydaktyków oraz studentów, co pozwala wysnuć wniosek o potrzebie dalszego rozpowszechniania wiedzy na temat modeli otwartości w nauce. Zarówno polscy grantodawcy, tacy jak Narodowe Centrum Nauki, jak i władze polskich uczelni coraz więcej uwagi poświęcają zagadnieniom Otwartej Nauki: udostępnianiu już nie tylko artykułów, ale i monografii naukowych, dzieleniu się surowymi i opracowanymi danymi w otwartych repozytoriach, profesjonalnemu zarządzaniu danymi badawczymi przez data stewardów czy wykorzystywaniu w edukacji akademickiej otwartych zasobów i narzędzi. Warto zatem bacznie obserwować wpływ formatu wydawniczego open access na widoczność i prestiż jednostek naukowych oraz badaczy - być może wkrótce będzie nie tylko mile widzianym dodatkiem, lecz również elementem ewaluacji czy wymogiem stawianym przez wszystkich fundatorów badań naukowych.

Włączenie się „Zagadnień Rodzajów Literackich” w promocję 12. Seminarium Open Access w Bibliotece Uniwersytetu Łódzkiego jest sygnałem, że rośnie świadomość środowiska naukowego - również redaktorów i wydawców prac naukowych. Redakcji czasopisma, którego wydawca (Łódzkie Towarzystwo Naukowe) już od kilku lat bezpłatnie udostępnia wersję online publikowanych tekstów, zależy na zwiększaniu swoich kompetencji i dbaniu o jakość udostępnianych treści. Ponadto patronowanie wydarzeniu mającemu na celu edukować i przedstawiać korzyści wynikające z otwierania (się) nauki to dla „Zagadnień Rodzajów Literackich" okazja, by opowiedzieć się po stronie powszechnego dostępu do wiedzy.

ANNA Zatora

(iD) https://orcid.org/0000-0003-4597-5568

Oddział Informacji Naukowej i Analiz Bibliometrycznych, Biblioteka Uniwersytetu Lódzkiego

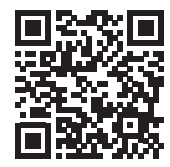

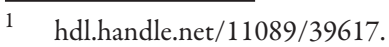

